PontIFícIA UNIVERSIDADE CATÓLICA dO RIO DE JANEIRO

Decisões do Futebol A Influência dos Stakeholders

Marcelo Abrantes

Trabalho de Conclusão de Curso

Centro de ciênCias sociais - CCS DePARTAMENTO dE AdMINISTRAÇÃO

Graduação em Administração de Empresas 
Marcelo Abrantes

\section{Decisões do Futebol A influência dos Stakeholders}

\section{Trabalho de Conclusão de Curso}

Trabalho de Conclusão de Curso, apresentado ao programa de graduação em Administração da PUC-Rio como requisito parcial para a obtenção do titulo de graduação em Administração.

Orientador(a) : Marcelo Piñeiro

Rio de Janeiro

Junho de 2016. 


\section{Resumo}

Abrantes, Marcelo. Piñeiro, Marcelo. Decisões do futebol, A influência dos stakeholders. Rio de Janeiro, 2016. Número de páginas 42. Trabalho de Conclusão de Curso - Departamento de Administração. Pontifícia Universidade Católica do Rio de Janeiro.

Este trabalho apresenta inicialmente, através de um contexto histórico, um cenário das relações existentes entre clubes de futebol no Brasil e seus principais stakeholders. No entanto, seu foco principal consiste nos processos de tomada de decisão presentes em um clube através da influência dos seus stakeholders. No processo de tomada de decisão existem vários modelos distintos. Os gestores em geral possuem características únicas que os diferenciam entre si, assim como as decisões que tomam.

Palavras- chave

Futebol, Stakeholder, Tomada de decisão.

\section{Abstract}

Abrantes, Marcelo. Footbal decisions, the influence of stakeholders. Rio de Janeiro, 2016. 42p. Trabalho de Conclusão de Curso - Departamento de Administração. Pontifícia Universidade Católica do Rio de Janeiro.

This work presents initially, through a historical context, a scenario of the relationship between football clubs in Brazil and its main stakeholders. However, its main focus is on decision -making processes present in a club through the influence of its stakeholders. In the decision -making process has several distinct models. The general managers have unique characteristics that differentiate them from each other, as well as the decisions they make.

Key-words

Football, Stakeholder, decision-making processes 


\section{Sumário}

1 O tema e o problema de estudo 1

1.1. Objetivo do estudo 4

1.2. Objetivos intermediários do estudo 4

1.3. Delimitação e foco do estudo 5

1.4. Justificativa e relevância do estudo 5

2 Referencial teórico 6

2.1. Os Stakeholders 6

2.2. Tomada de Decisão 8

2.2.1. Níveis de Tomada de Decisão 8

2.2.2. Decisões nas Organizações 10

2.2.3. Erros e Vieses na Tomada de Decisão 11

2.2.4. Atores do Processo Decisório e suas Diferenças 13

2.2.5. Critérios éticos no Processo Decisório 14

3 Métodos e procedimentos de coleta e de análise de dados do estudo 16

3.1. Etapas de coleta de dados 16

3.2. Fontes de informação selecionadas para coleta de dados no estudo16

3.3. Procedimentos e instrumentos de coleta de dados utilizados no estudo

3.4. Formas de tratamento e análise dos dados coletados para o estudo18

$\begin{array}{ll}\text { 3.5. Limitações do Método } & 18\end{array}$

4 Apresentação e análise dos resultados 20

4.1. Perfil dos Entrevistados 20

4.2. Descrição e análise dos resultados $\quad 21$

4.2.1. O Stakeholder Globo 21

4.2.2. O Stakeholder Torcida 23

4.2.3.Processos decisórios do Flamengo 26 
5 Conclusões e recomendações para novos estudos

5.1. Conclusões do estudo 31

5.2. Recomendações para novos estudos 33

6 Referencias Bibliograficas 34

7 Anexos $\quad 39$

7.1. Roteiro de Entrevista - Clube de Regatas Flamengo 39

7.2. Roteiro de entrevista - Grupo Globo 41

7.3. Roteiro de Entrevista - Representante da torcida 42

\section{Lista de figuras}

Figura 1 - A Organização e seus stakeholders ……………………………........ 7

Figura 2 - Níveis de Tomada de Decisão ………………………………...... 9

Figura 3 - Mapa de curtidas dos times no Brasil ............................................. 24

\section{Lista de Tabelas}

Tabela 1 - Premissas do modelo racional de tomada de decisão 10 


\section{0 tema e o problema de estudo}

O futebol é um dos esportes mais praticados no mundo nos tempos de hoje e, além de mexer com a paixão de muitas pessoas, vem crescendo economicamente e se mostrando um modelo de negócio cada vez mais rentável. Esse é um dos motivos pelos quais países sem muita tradição futebolística, como a China (Folha de São Paulo, 2014) e os Estados Unidos, (Globoesporte.com, 2014) têm investido pesado nesse setor.

$E$ quando o assunto é o futebol profissional atualmente, os clubes europeus estão no topo. Pode-se citar o caso do clube inglês Manchester United, (Mundo Deportivo, 2014), que no ano passado, foi o clube com maior verba de patrocínio no mundo, com um contrato de 61 milhões de Euros (em torno $\mathrm{R} \$ 187$ milhões na época). No Brasil, por outro lado, o clube hoje de maior patrocínio, (Estadiovip.com, 2015), é o Corinthians. O clube paulista arrecada em torno de $\mathrm{R} \$ 30$ milhões por ano, ou seja, uma diferença de $\mathrm{R} \$ 157$ Milhões com relação ao Manchester United. Além disso, o clube de Manchester possui seu valor mensurado por 3,10, bilhões de Dólares, segundo a revista Forbes, já o Corinthians, por apenas 358 milhões de Dólares (Esportesterra.com, 2015).

Os maiores clubes do Brasil, hoje em dia, são Instituições que possuem o futebol profissional como o seu maior e mais rentável negócio e, em função dele, ocorrem diversas interações com os numerosos stakeholders, também denominados como players, existentes nesse mercado. Essas relações que, além de terem sofrido inúmeras mudanças com o passar do tempo, variam desde a relação do seu cliente final (os torcedores) com seu clube, até de entidades esportivas e emissoras de transmissão.

Entende-se "stakeholders", como todas as partes interessadas presentes no ambiente do negócio (Evan e Freeman, 1988). No caso do setor envolvendo futebol, existem diversos outros com essa denominação. Ao relaciona-los com um clube em questão, pode-se dividi-los em dois grupos. Podem ser internos, ou seja, presentes dentro do clube, como por exemplo, atletas e comissão técnica, e externos, que são as entidades, as emissoras de transmissão, e os torcedores, entre outros. 
No entanto, essa relação do esporte como forma de negócio nem sempre existiu aqui no Brasil. Fazendo uma retrospectiva da história do futebol brasileiro, não se sabe de forma tão concreta quando ele surgiu. Acredita-se que foi através de Charles Miller (Uol, 2015), um brasileiro que estudava na Inglaterra, onde teria tido contato com esse esporte, e que trouxe a primeira bola para 0 país no final do século XIX.

Foi mais ou menos nesta época que vários clubes, ditos como grandes no cenário nacional, como o Clube de Regatas Vasco da Gama e o Clube de Regatas Flamengo foram criados, mas, diferentemente de outros países onde vários clubes surgiram de organizações com fins lucrativos, aqui no Brasil eles originalmente nasceram como clubes esportivos, tidos como espaços para o convívio social e prática esportiva. Eles foram criados sob a forma de associações, ou seja, organizações democráticas autônomas sem fins lucrativos, e que possuíam, como base, o trabalho voluntário por parte dos seus dirigentes (Mattar, 2014). Portanto, além de não haver a mesma quantidade de stakeholders, os que existiam, não possuíam a mesma influência que se tem hoje em dia, até porque o nível de profissionalização no futebol era comparativamente muito mais baixo.

Apenas em 1914 (Cpdoc.fgv, 2006) foi criada a CBD (Confederação Brasileira de Desportos), a primeira entidade (Stakeholder) que administrava o futebol nacional, e que, em 1979, seria sucedida pela CBF (Confederação Brasileira de Futebol). Atualmente, além dela, cada estado possui uma federação responsável pela regulação dos times de futebol e competições locais, por exemplo, a FERJ (Federação de Futebol do Estado do Rio de Janeiro), e a FPF (Federação do futebol Paulista). Esses agentes, apesar de serem responsáveis pela estruturação e administração do futebol de seus respectivos estados, são frequentemente criticados por outros, como a mídia e pelos próprios clubes, por exemplo, por serem consideradas sustentadas por receitas originadas pelos clubes (Noticiasuol.com, 2015).

Foi só na década de 90, que o futebol brasileiro começou a se tornar cada vez mais rentável (Mattar, 2014). Com aumento da visibilidade, e, em função do ganho das receitas de patrocínio e de cotas de transmissão, nunca houve tanto poder econômico nos clubes de futebol do país como a partir daquela época. Como o Brasil tem uma cultura monoesportiva, na qual o futebol se sobressai muito mais em relação aos outros esportes, ao contrário do que ocorre nos Estados Unidos, por exemplo, (Mattar, 2014), a rentabilidade do esporte nos anos 90 influenciou o surgimento dos primeiros canais exclusivamente 
esportivos. Contudo, a televisão, como detentora dos direitos de exibição dos jogos, passou a influenciar diretamente na estrutura do campeonato, como por exemplo, no calendário e nos horários que cada time joga (esporte.uol.com, 2015).

Outro fundamental stakeholder e, talvez, o mais importante deles, é o cliente final, os torcedores. É para eles que os clubes designam suas ações, pois se trata de uma fundamental fonte de receita, como em vendas de ingressos e plano de sócio torcedor, por exemplo. O torcedor também está indiretamente ligado a outros agentes, como no caso da audiência obtida pela televisão, na qual os clubes considerados grandes recebem muito mais pelas cotas de transmissão, que os considerados pequenos (Globoesporte, 2013). Outro exemplo é com a venda de camisas oficias, onde não só os clubes, mas também os fornecedores de materiais esportivos adquirem parte de suas receitas (universidadedofutebol.com, 2010).

Toda organização deve adotar medidas que considerem a influência da tomada de decisão para com os diversos agentes existentes, e, também considerar a deles para a própria organização (Evan e Freeman, 1988), e, no futebol profissional moderno, não se pode negar que os stakeholders presentes influenciam diretamente as ações realizadas pelos clubes de futebol.

Pode-se citar como exemplo quando um clube decide contratar um jogador que pode ser fundamental para o seu desempenho no campeonato, mas não possui condições financeiras para contratá-lo, com isso, acaba dependendo de investidores externos para concluir a operação. É uma prática bastante comum no futebol nacional e, até o ano de $2014,80 \%$ dos jogadores brasileiros não pertenciam totalmente aos clubes que jogavam (prática que a FIFA passou a proibir a partir de maio de 2015 (Globoesporte.com, 2014)). Neste caso, como o clube não detém a maior parte dos direitos econômicos do atleta, ele pode ser obrigado a vendê-lo em um momento crucial da temporada, caso haja propostas financeiramente vantajosas para o jogador e para os investidores.

Outro exemplo são os adiantamentos de direitos de transmissão a pedido dos clubes. Também são bem comuns, devido à fragilidade financeira dos times brasileiros, que dependem desse dinheiro para quitar suas dívidas fiscais e salários atrasados, entre outras (Espnuol.com, 2014). Entretanto, essa prática está dificultada atualmente, uma vez que os detentores dos direitos de transmissão não têm mais aceitado os pedidos dos clubes como costumava aceitar, o que, em curto prazo, pode afetar negativamente o clube por não 
conseguir honrar seus compromissos, mas, a longo prazo, talvez o ajudará, já que o mesmo provavelmente não assumirá uma nova dívida.

Visto isso, percebe-se o quanto a gestão de um time está fortemente relacionada aos players existentes, e que precisam ser devidamente geridos, pois os mesmos possuem uma influência direta nas decisões optadas por um clube de futebol.

Desta forma a pergunta que norteia o estudo é: qual a influência dos stakeholders nos processos de decisão de um clube de futebol?

\subsection{Objetivo do estudo}

Esse trabalho tem como objetivo identificar os processos presentes na Teoria do Modelo de Tomada de Decisão que um clube de futebol executa ao ser influenciado pelos seus stakeholders.

\subsection{Objetivos intermediários do estudo}

$>$ Definir o conceito de stakeholders.

$>$ Apresentar e descrever os conceitos de tomada de decisão dentro da administração

$>$ Pesquisar a respeito do clube definido.

Identificar e descrever Stakeholders influentes no futebol do clube.

$>$ Identificar processos decisórios presentes no clube estudado

Apresentar e descrever processos decisórios identificados. 


\subsection{Delimitação e foco do estudo}

Este estudo se limita apenas ao setor de futebol do Clube de Regatas Flamengo. São priorizados dados recentes (2014-2016) a respeito das práticas de gestão de relação com os stakeholders envolvidos. Contudo, existem alguns dados mais antigos para que se possa contextualizar com os atuais. Esse estudo foca apenas nas relações do clube com dois agentes externos do microambiente, são eles: a torcida e o Grupo Globo. Não são objetos de foco nesse estudo atletas ou outros colaboradores. As relações presentes entre os stakeholders envolvidos com os clubes serão apresentados de forma ampla, porém, os processos de decisão tomados pelo clube, por influência deles, são o foco principal deste trabalho.

\subsection{Justificativa e relevância do estudo}

Este estudo é relevante para entender como os gestores de um time grande do cenário nacional administram o clube de futebol. É fundamental que se entenda até que ponto esses profissionais são capazes de escolher as melhores decisões a serem tomadas e, como os stakeholders influenciam para que as tomem.

Esse estudo pode servir de subsidio para futuros profissionais que desejam entrar no meio esportivo e, desejam entender como ocorre essa relação de clube com seus agentes externos, e, portanto, possam compreender que tipos de decisões uma instituição, das mais importantes do esporte nacional, opta. Também é interessante para qualquer adepto do esporte, e principalmente de futebol, que deseja conhecer mais a respeito de gestão de clube. E para os torcedores do time estudado que buscam informações mais a fundo sobre os bastidores da administração do futebol, e também como os processos internos de decisão ocorrem.

O trabalho servirá de apoio para novos estudos acadêmicos vinculados à área de gestão esportiva e para uma melhor compreensão dos processos decisórios presentes em uma organização. 


\section{Referencial teórico}

Neste capitulo, inicialmente será abordada de forma sucinta a relação entre uma organização e seus stakeholders. Posteriormente, o estudo abordará os processos de tomada de decisão presentes numa estrutura organizacional. Serão abordados os níveis em que as decisões ocorrem, processos comuns de tomada de decisão, erros e vieses, e o envolvimento ético na tomada de decisão.

\subsection{Os Stakeholders}

Entendem-se como Stakeholders, todos os indivíduos afetados pelas atividades executadas por uma organização. Como dito no primeiro capitulo deste estudo, são todas as partes interessadas presentes no ambiente do negócio (Evan e Freeman, 1988). Trata-se de um termo oriundo de "stockholder", que representa os acionistas, ou seja, o que anteriormente era entendido por satisfazer apenas os interesses dos acionistas, posteriormente, passou também focar na satisfação dos outros agentes presentes no ambiente da Organização (Goldschimidt e Rocha, 2011).

A Figura a seguir ilustra como esses stakeholders podem influenciar e serem influenciados pela organização. Existe uma relação mútua entre as partes. 


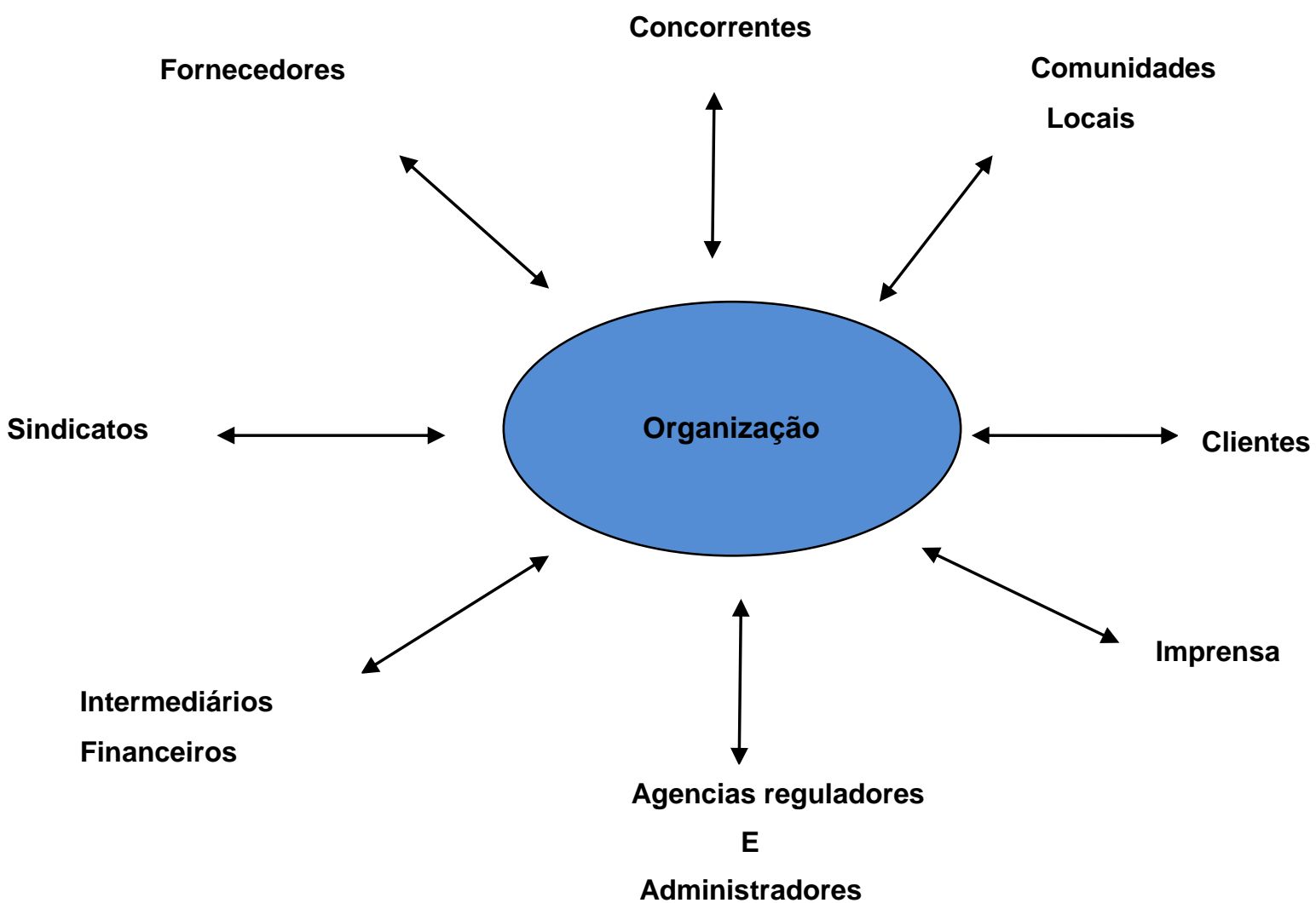

Governamentais

Figura 1 - A organização e seus Stakeholders

(Adaptada de, Goldschimidt e Rocha, 2011).

O cliente é o que costuma ser o mais estudado e o mais importante dentre todos eles, pois é em função dele que as organizações criam seus produtos, traçam suas estratégias, além de buscarem criar novas ações para atendê-lo cada vez melhor. Uma empresa não existe sem seus clientes, (Goldschimidt e Rocha, 2011).

Já os concorrentes, são outras empresas que competem pela participação de mercado que determinada organização ocupa. As agências e órgãos governamentais são os agentes que regulam a atuação da empresa no mercado, e os fornecedores, são os que atuam diretamente na cadeia produtiva da empresa, é com eles que as organizações buscam produtos e serviços para o seu funcionamento (Goldschimidt e Rocha, 2011).

Também pode-se ver a imprensa, que se trata de um stakeholder o qual a organização precisa sempre estar atento, pois pode interferir no rumo negativo ou positivo da mesma perante o público. 
Há também a presença dos intermediários financeiros e as comunidades locais. O primeiro é representado por bancos, que costumam auxiliar as organizações na sua saúde financeira, como por exemplo no caso de empréstimos e investimentos futuros. Já o segundo, são os membros pertencentes nas áreas próximas onde a empresa se encontra. Pode se tratar de indivíduos ou mesmo até de outras empresas.

Por fim, a presença dos sindicatos, é através deles que os colaboradores da organização têm seus interesses representados, onde o objetivo principal é manter uma relação harmônica entre funcionários seus empregadores (Goldschimidt e Rocha, 2011).

Existem também os stakeholders internos, como é o caso dos proprietários, dos diretores, gerentes e funcionários, contudo, assim como explicado nas delimitações deste estudo, este estudo foca apenas nos stakeholders externos, que se encontram presentes no microambiente da empresa (Goldschimidt e Rocha, 2011).

\subsection{Tomada de Decisão}

Dentro de uma organização sempre existiram processos decisórios, dos quais diversos agentes, sejam eles internos ou externos envolvidos, estão todos conectados às causas ou consequências dessas decisões. São processos que estão sempre presentes no dia a dia das organizações, e a todo tempo os seus membros estão diante de situações onde é necessário analisar, e definir, por poucas ou muitas opções de decisão existentes (Moritz, Pereira, Préve, 2010).

\subsubsection{Níveis de Tomada de Decisão}

A organização pode ser dividida em três níveis de tomada de decisão, são eles: Estratégico, Tático e Operacional. Cada um destes tipos de decisão corresponde a um nível organizacional, como demonstrado a seguir: 


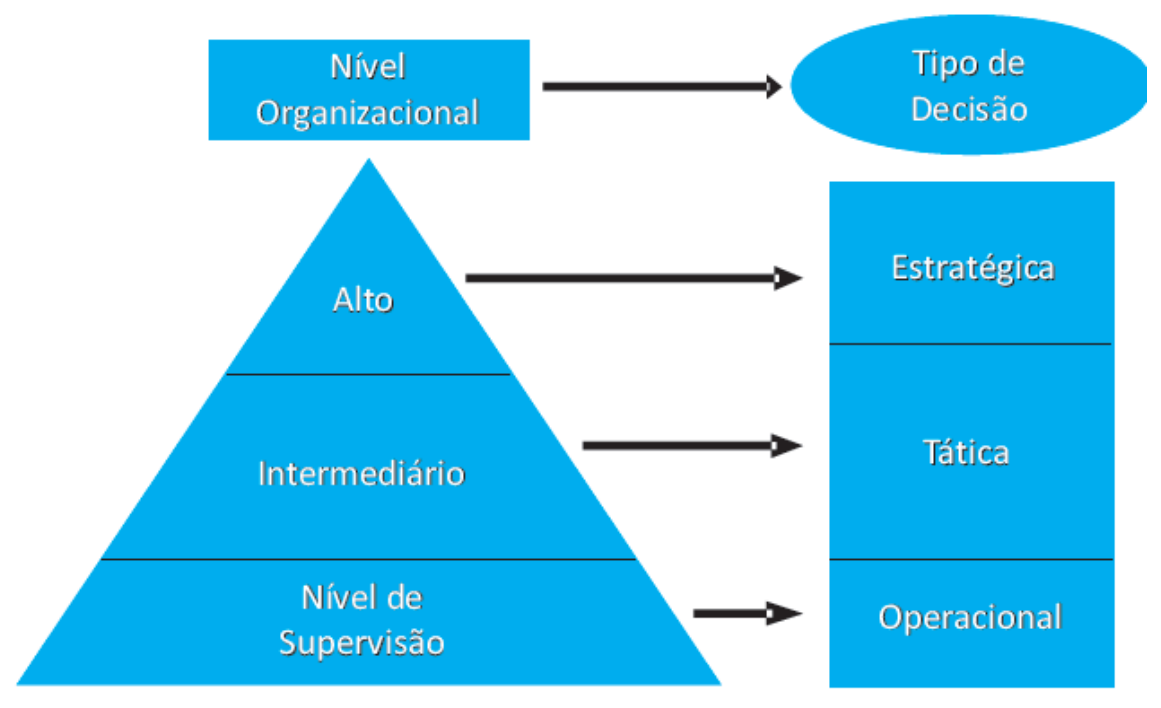

Figura 2 - Níveis de Tomada de Decisão

(Adaptada de, Moritz, Pereira, Préve, 2010).

No topo, encontra-se o nível denominado Alto da hierarquia organizacional. Nesta área que os gestores determinam as metas, quais produtos e serviços oferecer ao cliente e, quando e onde a empresa deve agir (Judge, Robbins, e Sobral, 2011), é onde as decisões estratégicas são tomadas. Essas decisões determinam os objetivos da organização e qual rumo deve ser seguido e, como ela lidará com o ambiente externo, definindo qual a melhor decisão a ser tomada (Moritz, Pereira, Préve, 2010). O modelo é representado pelos altos executivos da organização e suas decisões possuem maior impacto dentro e fora da organização, com relação aos níveis abaixo.

O segundo nível é o intermediário, onde se encontra o nível gerencial da organização. Neste caso, os membros envolvidos costumam serem gerentes de departamentos ou de divisão, por exemplo, (Moritz, Pereira, Préve, 2010). É nele que estão presentes as decisões táticas que correspondem a decisões mais específicas, como por exemplo, treinamento, compra, contratação, entre outras.

Já o terceiro nível, é o de Supervisão, no qual seus membros assumem funções e decisões em nível operacional. São processos decisórios que determinam como as operações devem ser conduzidas, e são definidas através das decisões táticas (Moritz, Pereira, Préve, 2010). Elas também são tomadas para definir como as operações devem ser feitas e quanto esforço será necessário para a execução das tarefas (Judge, Robbins, e Sobral, 2011). 


\subsubsection{Decisões nas Organizações}

Após apresentar os níveis organizacionais de tomada de decisão, é importante que se entenda como as decisões são tomadas pelas pessoas na realidade. Essa etapa consiste em abordar três modelos distintos a respeito de domada de decisão, são eles: os modelos, Racional, o de Racionalidade imitada, e por último, o Intuitivo.

O modelo Racional se baseia na hipótese de que a pessoa que irá tomar qualquer decisão possui total conhecimento de todas as informações a respeito do problema e, consiga chegar a todas as alternativas possíveis, para escolher aquela que trará o melhor resultado (Judge, Robbins, e Sobral, 2011).

Em função disso, esse modelo se baseia em seis premissas, das quais se consiga chegar a melhor opção na tomada de decisão. Segue abaixo a tabela contendo as seis premissas:

\begin{tabular}{|c|c|}
\hline \multicolumn{2}{|c|}{ Premissas do modelo racional de tomada de decisão } \\
\hline 1 & Definir o problema \\
\hline 2 & Identificar os critérios para a decisão \\
\hline 3 & Atribuir pesos para cada critério \\
\hline 4 & Formular alternativas \\
\hline 5 & Avaliar alternativas \\
\hline 6 & Escolher a melhor alternativa \\
\hline
\end{tabular}

Tabela 1 - Premissas do modelo racional de tomada de decisão (adaptada de Judge, Robbins, Sobral, 2011).

O segundo Modelo é o de Racionalidade Limitada, que pode ser entendido como a capacidade limitada que as pessoas possuem de entender todas as informações necessárias para se tomar uma decisão. Ou seja, as pessoas costumam pensar o problema de maneira mais simples, de forma a conseguir compreende-lo melhor. Segundo Robbins, são construídos modelos simplificados para extraírem os aspectos essências dos problemas, sem capturar toda a sua complexidade (Judge, Robbins, e Sobral, 2011, p169). As pessoas quando recebem informações acabam filtrando-as de maneira que consiga aplica-las a outros conceitos já pré-estabelecidos por elas antes. Essas filtragens costumam acontecer de forma inconsciente e automática por elas e, por isso, 
podem acabar abstraindo informações que poderiam ser úteis (Bazerman e Moore, 2009).

Para Hebert Simon, (citado por Fernandez. e Steingraber, 2013), nesse modelo em questão, é demonstrada a falta de capacidade que as pessoas possuem de compreender todas as informações que recebem. É comum que as pessoas acabem ignorando informações que para elas são estranhas e incomuns, ou até opções excessivas. É bem comum que indivíduos se sintam sobrecarregados com um volume muito grande de informação (Bazerman e Moore, 2009). Sendo que a mesma pode ser imperfeita e incompleta. Não existe um conjunto lógico de alternativas das quais se pode escolher a melhor (Fernandez e Steingraber, 2013). Muitas vezes se opta por aquela suficientemente satisfatória, porém não se sabe se esta é a melhor opção.

O ultimo modelo, o de Tomada de Decisão Intuitiva, para Robbins, trata-se de um processo cognitivo apoiado por experiências vividas (Judge, Robbins, e Sobral, 2011, p. 170). Ou seja, não ocorre conscientemente pelas pessoas, e pode acontecer de maneira rápida e inesperada. Nela, o indivíduo acaba optando pela decisão a ser tomada naquele momento e, segundo o mesmo, muitas vezes funciona a base de emoções, possuindo um grande componente afetivo.

\subsubsection{Erros e Vieses na Tomada de Decisão}

Muitas vezes as decisões escolhidas nem sempre são as melhores. Existem diversos tipos de erros e vieses comuns nesse processo. Nessa etapa, serão abordados erros e vieses comuns, cometidos ao se tomar uma decisão.

Um dos erros mais presentes é o excesso de confiança. Muitas vezes, ele pode culminar no insucesso de um projeto ou negócio em função de escolhas feitas base de atrevimento e imprudência.

Existem também outros, como o de aleatoriedade e o de aversão ao risco. Para Robbins, o primeiro pode ser definido como acreditar na ideia de se prever resultados em função de acontecimentos aleatórios (Judge, Robbins, e Sobral, 2011, p. 173). O que quer dizer que muitos acontecimentos ocorridos por mero acaso, para certas pessoas, podem servir de base para explicar outros eventos. Talvez não seja ideal se pensar que o sucesso ou fracasso de uma operação será determinado por sorte e sim por competência das partes envolvidas. Já o 
segundo, o autor define como a preferencia de um ganho mais certo, a se arriscar por um ganho maior. Às vezes pode ser mais sensato tomar uma decisão mais segura que já garanta um resultado satisfatório do que optar por outra de maior risco. No entanto, isso pode limitar os resultados a serem alcançados.

No que diz respeito aos vieses, pode-se citar o viés da ancoragem. Ele ocorre quando as pessoas se prendem a primeiras ideias e impressões a respeito de alguma informação, o que dificulta a mudança e o ajuste da mediante de informações posteriores. Pode ser muito útil num processo de negociação, por exemplo, ao tentar passar para o interessado as informações mais relevantes para obter aceitação do mesmo (Judge, Robbins, e Sobral, 2011). Diferentemente do viés de disponibilidade, o qual se tende a utilizar apenas informações facilmente acessíveis sobre determinado assunto. Neste caso, o tomador de decisão se prende apenas a informações que podem ser superficiais demais e não consegue compreender totalmente um problema em questão. O que pode dificultar o processo decisório por parte dele.

Há também os vieses de escalada de comprometimento, e a compreensão tardia. O primeiro representa a dificuldade que um gestor possa ter de tomar novas atitudes por estar preso a decisões anteriores, que além de não muito boas, as considera de alguma forma positiva. Ou seja, após uma escolha equivocada, o gestor por não querer mudar de ideia, pode acabar desperdiçando recursos da organização à toa. Já o segundo, corresponde, segundo Robbins, como a tendência das pessoas quererem acreditar que sabiam do resultado de um evento antecipadamente, depois do mesmo ter sido concluído (Judge, Robbins, e Sobral, 2011, p. 175). O que quer dizer que o individuo quer passar uma imagem que possui uma visão diferenciada com relação aos outros. $O$ autor também diz que se trata de um viés que reduz a capacidade das pessoas a aprenderem com o passado. Numa organização, um gestor pode cometer alguns erros similares, justamente por tentar acreditar ser capaz de prever um resultado positivo, ou pelo menos passar essa imagem.

Por fim, outro viés decisório bastante presente é o da evidencia confirmadora, no qual a pessoa se utiliza de informações que corroborem com suas escolhas e suas decisões. Nesse modelo, tende-se a aceitar melhor as informações que confirmem conceitos já pré-concebidos e, consequentemente, se opor a todo tipo de informação que contrarie esses conceitos. A tendência é que indivíduos utilizem esse viés para apresentar dados que confirmem aquilo que eles já saibam, (Judge, Robbins, e Sobral, 2011). 


\subsubsection{Atores do Processo Decisório e suas Diferenças}

Foi visto anteriormente como são distribuídas as tomadas de decisão dentro da organização e também seus principais modelos. Além disso, foram exploradas as principais falhas que muitos gestores podem cometer ao tomarem uma decisão. No entanto, é preciso identificar quem são esses tomadores de decisão e quais as suas diferenças.

Os atores do processo decisório, na maior parte das vezes, são certos indivíduos isolados dentro de uma organização que possuem mais poder em relação à maioria. Podem ser diretores de departamento, gerentes e presidentes, por exemplo. Contudo, também existem casos em que as decisões são tomadas por um grupo de pessoas, como o caso de um conselho administrativo ou de diretor (Moritz, Pereira, Préve, 2010).

Podem existir num ambiente organizacional diversos tomadores de decisão e, os mesmos possuem suas próprias características, que podem influenciar em qual alternativa será escolhida. Essas diferenças variam de pessoa para pessoa, e pode ser tanto em função da personalidade dela, quanto de gênero e habilidade mental (Judge, Robbins, e Sobral, 2011).

Robbins explica que não existem tantos estudos a respeito de personalidade e tomada de decisão, mas já é comprovado que a primeira está diretamente ligada à segunda (Judge, Robbins, e Sobral, 2011, p. 175). Também cita que pessoas que são voltadas para a realização tendem a se esforçar mais para evitar o fracasso, pois odeiam falhar. Assim como, as que possuem personalidade de serem mais dedicadas nas suas tarefas, não parecem ver o sucesso como principal objetivo, e apenas querem fazer o que acham melhor para a organização (Judge, Robbins, e Sobral, 2011).

Já no caso da diferença de gêneros, segundo o mesmo, as mulheres tendem a refletir mais antes de tomarem uma decisão do que os homens, em geral. Ou seja, elas costumam pensar mais nas consequências e nas outras possibilidades de caminhos que possam ser seguidos e, às vezes até exageram nesse processo. Diferentemente dos homens, que tendem a pensar menos e agirem mais, o que muitas vezes pode ser imprudente, porém, pode acontecer de não se ter muito tempo para tomar melhor decisão a ser seguida (Judge, Robbins, e Sobral, 2011, p. 176). 
Os indivíduos que possuem uma melhor capacidade de processamento de informações podem ser destacados por possuírem habilidade mental mais alta. Portanto, são capazes de resolver problemas e chegarem a melhores soluções com mais facilidade. O autor explica que apesar dessa característica fazer parecer que pessoas com o nível de habilidade mental mais alta, costumam se equivocar menos no processo decisório, eles, assim como os que possuem menos dessa habilidade, são igualmente suscetíveis às falhas na hora de decidirem que opção escolher, porém, os que possuem um nível maior de habilidade mental podem aprender mais facilmente com os erros e equívocos cometidos anteriormente (Judge, Robbins, e Sobral, 2011, p. 177). Toda organização é composta deste desnível de habilidade, pois cada pessoa tem sua própria habilidade mental, que a difere da outra. Talvez não se saiba até que ponto os principais tomadores de decisão são os que possuem mais esta habilidade com relação aos demais.

\subsubsection{Critérios éticos no Processo Decisório}

Dentro dos processos decisórios existem alguns critérios éticos presentes a cada tomada de decisão. São eles, o utilitarismo, o de decisões coerentes à liberdade e os direitos, e o ultimo, que está relacionado ao cumprimento de regras e na imparcialidade (Judge, Robbins, e Sobral, 2011).

Entende-se utilitarismo como o processo ético que faz com que a pessoa que está tomando as decisões, pense nos resultados e nas consequências delas. Portanto, o seu principal objetivo é obter o melhor resultado para a maioria das partes interessadas. Apesar disso, é importante dizer que nesse critério, dificilmente as vontades e as necessidades de todos serão visados, a maioria é a prioridade (Judge, Robbins, e Sobral, 2011). Contudo, talvez dificilmente uma organização consiga algum avanço relevante, seguindo os interesses de todos os seus membros.

Já o segundo critério, o que prioriza optar por decisões coerentes a liberdade, tenta focar ao máximo na justiça e na igualdade de direitos de todos. Portanto, nesse tipo de critério, os membros da organização se encontram mais protegidos pela mesma para executar suas ações (Judge, Robbins, e Sobral, 2011). Porém, muitas vezes essas ações possam sair do âmbito legal da justiça, causando até prejuízos à organização contra órgãos reguladores, por exemplo. 
No que diz respeito ao ultimo critério, ele tem como objetivo central a imparcialidade e a igualdade dos membros envolvidos. Para Robbins, é o critério mais preferido pelos sindicalistas, por exemplo, (Judge, Robbins, e Sobral, 2011, p. 178). Pode- se dizer que, de todos os três, este é o que predomina os direitos iguais para todos da organização. Com isso, independentemente do desempenho de uma pessoa ser superior à outra, e ambas exercem a mesma função, não quer dizer que a primeira pessoa possa ser vista como superior. 


\section{Métodos e procedimentos de coleta e de análise de dados do estudo}

\subsection{Etapas de coleta de dados}

Esse estudo exige um modelo de pesquisa exploratória para sua coleta de dados. Para assim, conseguir identificar os processos decisórios que o clube executa, por ser influenciado pelos stakeholders.

Entende-se pesquisa exploratória como o método utilizado para se obter informações que desenvolvam, esclareçam e modifiquem conceitos (Gil, 2008) Nesse método, além de apresentar uma visão mais ampla de determinado tema, ele não se destina a uma conclusão final, e sim, em gerar oportunidades que outros pesquisadores possam apresentar estudos posteriores (Barry e William, 2011).

\subsection{Fontes de informação selecionadas para coleta de dados no estudo}

Esse estudo conta com a utilização de dados secundários e de entrevistas por parte do pesquisador. Sendo o primeiro obtido através de livros acadêmicos de administração, matérias de jornais, e de livros e artigos a respeito de gestão esportiva e do clube estudado. Já o segundo, foi realizado entrevistas, durante o primeiro semestre do ano de 2016, com três fontes distintas: um representante do Clube de Regatas Flamengo, um da Globo, e outro importante membro de uma torcida organizada do clube.

As entrevistas têm como objetivo entender a influência dos stakeholders nas ações tomadas pelos gestores do clube, e com isso identificar os processos de decisão tomados pelos mesmos e seus vieses (os roteiros utilizados nas entrevistas encontram-se nos anexos deste estudo, p 39).

Já os dados secundários, visam à coleta de informação sobre o clube em questão e os seus stakeholders, que estão previamente delimitados, além de servirem de apoio para a obtenção dos resultados. 
No caso do Flamengo, foi feito uma entrevista com um membro da equipe de marketing do clube, a respeito das relações existentes entre o clube com a Globo e como a sua torcida.

$\mathrm{Na}$ Globo, a entrevista foi feita com um membro da gerência das relações do Grupo Globo com todos os esportes. A entrevista foi a respeito das relações da Globo com os clubes de futebol brasileiros e o papel dela como parceira comercial dos mesmos.

No que diz respeito à torcida, foi conduzida uma entrevista com um expresidente e um dos fundadores da torcida Flamanguaça. Ela teve como foco a visão da torcida com as relações do Flamengo e seus stakeholders e, qual o papel do clube para com a torcida.

\subsection{Procedimentos e instrumentos de coleta de dados utilizados no estudo}

Estão presentes nestes estudos dois instrumentos de coleta de dados, são eles: Coleta de dados Secundários e Entrevista Pessoal.

Entendem-se como dados secundários, as informações que já foram unidas e registradas anteriormente por outros pesquisadores (Barry e William, 2011). Possui como vantagens a grande quantidade de informação disponível e também a sua facilidade de obtenção. A internet é um bom exemplo disso, é um canal onde se pode encontrar facilmente esse tipo de dado, contudo é preciso se ater mais à sua veracidade.

Já o processo de entrevista é aquele em que o pesquisador se apresenta frente a frente ao entrevistado, fazendo-lhe perguntas para obter dados que interessem a sua pesquisa. Uma das grandes vantagens desse método, é o feedback direto por parte do entrevistado, como por exemplo no esclarecimento de uma das perguntas, de forma que, o entrevistado compreenda melhor e possa contribuir com uma informação mais rica. Esse método possibilita que o pesquisador se adapte rapidamente a situação para obter maior qualidade na informação (Gil, 2008).

Num primeiro momento serão utilizados apenas dados secundários para fundamentar e contextualizar o tema proposto. O processo de entrevista se inicia posteriormente, depois de toda consolidação da estrutura inicial deste trabalho, para que se possibilite a fundamentação dos conceitos a serem aplicados no 
roteiro base. Além disso, os contatos com os entrevistados se iniciaram no andamento deste estudo.

\subsection{Formas de tratamento e análise dos dados coletados para 0 estudo}

Após as etapas de coleta de dados será feita uma análise qualitativa por parte de pesquisador. Primeiramente será feita um processo de redução de todos os dados obtidos, ou seja, ocorrerá uma simplificação das amostras (Gil, 2008). Os dados serão filtrados para que não haja impurezas no estudo.

O segundo método será o de análise de conteúdo, o qual o pesquisador revisará todos os dados obtidos e, serão excluídos todos aqueles que demonstrarem falta de veracidade, ou fonte indevida. No que diz respeito à etapa de entrevistas, as informações coletadas que demonstrarem algum tipo de tendenciosidade por parte dos entrevistados serão excluídas.

\subsection{Limitações do Método}

Foram percebidas no processo de pesquisa desse estudo algumas limitações com relação aos métodos utilizados.

No que diz respeito à coleta de dados secundários, muitos dados não possuem uma fonte muito confiável, além disso, por se tratar de um tema relacionado a esporte, muitos dados são obtidos através de matérias jornalísticas, o que quer dizer que, muitas informações podem ter sido meras especulações ou até a opinião dos autores.

O processo de entrevista também possui diversas limitações. Pode se citar, por exemplo, a falta de interesse do entrevistado em responder certas questões, a incapacidade dele de responder certas questões e, pode acontecer também do próprio entrevistador deixar que opiniões pessoas o influenciem a respeito das informações dadas pelo entrevistado (Gil, 2008). A quantidade de entrevistados também pode não ser a ideal, isso muito em função da dificuldade de se obter os contatos por parte do pesquisador, além disso, todos os entrevistados possuem tempo limitado para entrevista. Por isso, é necessário conseguir todas as informações necessárias de cada entrevistado para o estudo obter melhores resultados. O próprio representante da torcida, que foi entrevistado, exerce uma função de Conselheiro do clube, o que pode ocasionar 
alguns vieses nas informações coletadas, pois o mesmo possui acesso a informações internas que a maior parte deste stakeholder não possui. 


\section{Apresentação e análise dos resultados}

\subsection{Perfil dos Entrevistados}

Conforme apresentando no capitulo anterior, esse estudo se utiliza do método de pesquisa exploratória para a coleta de dados secundários e do procedimento de entrevista pessoal. As entrevistas ocorreram com dois executivos, um do Clube de Regatas Flamengo e outro da Globo, e um representante de destaque da torcida.

No Flamengo, o clube foco deste estudo, foi feita uma entrevista pessoal com um representante do departamento de marketing do clube. Segundo o mesmo, o departamento de marketing do Flamengo cuida de todas as propriedades do clube, todos os seus produtos, e é dentro dele que se administram quase todas as receitas do clube.

O entrevistado do Stakeholder Globo trabalha na área de gerência das relações do Grupo Globo com todos os esportes. O seu campo de atividade gira em torno de parcerias com diversos stakeholders, que o mesmo considera parceiro, presentes no ambiente esportivo. Trata-se de clubes, federações, confederações, promotores de eventos, toda e qualquer tipo de entidade que trabalhe com esporte, para assim gerar conteúdo que possa ser transmitido na T.V. Globo e nos outros canais do grupo voltados para esporte.

Como membro de destaque da torcida, foi entrevistado um dos fundadores e ex-presidente da torcida organizada Flamanguaça, e atualmente é conselheiro do clube. Trata-se de uma torcida que surgiu sem o intuito de se tornar uma torcida organizada, diferente da Raça Rubro-Negra e da Torcida Jovem Do Flamengo (Organizadasbrasil.com, 2016) e, foi ganhando destaque e crescimento conforme os anos se passaram.

A Flamanguaça, segundo o entrevistado, surgiu no início da década de 1990 a partir de um grupo de amigos se reuniam para confraternizar antes dos jogos do Flamengo no Maracanã e, como o termo "manguaça" era comum na época para se denominar cerveja, o grupo de amigos idealizou o nome Flamanguaça e assim passou a criar materiais customizados como bandeiras, por exemplo, para levar os jogos. A torcida foi ganhando cada vez mais 
destaque e presença nos jogos do clube conforme anos se passaram e se tornou uma das de maior destaque nos jogos do clube.

\subsection{Descrição e análise dos resultados}

Neste tópico são abordadas as relações existentes dos agentes Globo e Torcida com o Clube de Regatas Flamengo. Os demais stakeholders citados nas entrevistas não foram analisados por motivos de inacessibilidade. Primeiramente serão abordadas amplamente as relações existentes entre a Globo no futebol Brasileiro e com o Flamengo, assim como a relação da torcida com o clube, depois serão apresentados e discutidos os processos decisórios e seus vieses identificados no clube em questão.

\subsubsection{Stakeholder Globo}

Trata-se do maior grupo de mídia brasileiro, um dos maiores do Mundo (Oglobo.com, 2016), e um dos principais agentes do futebol Brasileiro, segundo o representantes do Flamengo e da torcida. Além de possuir em torno de 120 emissoras afiliadas pelo país e, um alcance de conteúdo para 98,44\% das cidades brasileiras (Redeglobo.com, 2016), o Grupo Globo hoje é o maior comprador de conteúdo esportivo do país e, em função disso, não se pode negar o tamanho de sua importância para os clubes, dos quais possuem relações comerciais, e com os torcedores, que assistem seus conteúdos de futebol.

Para a Globo, um clube de futebol é uma entidade que sozinha não existe, ela depende de outros stakeholders para sobreviver, ele necessita de outros clubes concorrentes, da sua torcida, de uma entidade que organize suas competições, além de patrocinadores, veículos de mídia, entre outros. Todos estes citados são fundamentais para a composição de receita de um clube de futebol.

No futebol nacional é a Globo que contém a maior parte dos direitos de transmissão dos jogos, sendo que, esse tipo de relação varia de acordo com a competição. Esses direitos adquiridos podem ser pagos diretamente aos clubes e também para outros stakeholders, como o caso das Federações e Confederações, por exemplo. No Campeonato Carioca e na Copa do Brasil, a Globo negocia e compra os direitos com a FFERJ e para a CBF 
respectivamente, e as mesmas repassam os valores para os clubes. Já no caso da Série A do Campeonato Brasileiro de Futebol, a negociação ocorre de clube a clube, pois, segundo o entrevistado, antes a negociação era feita com o extinto Clube Dos 13, entidade que representava os principais times do Brasil e, após o seu desmanche, essa relação da Globo com os times da série A passou a ser feita dessa forma.

$\mathrm{Na}$ ótica dos principais clubes do país, a receita originada dos direitos de transmissão é muito valiosa, pois se trata de uma das maiores fontes de receita obtidas por um clube grande. Para se ter uma ideia, o faturamento anual previsto para o Flamengo é em torno de R $\$ 200$ milhões entre 2019 e 2014, (Época.com, 2016). Além disso, o entrevistado destacou que a importância da receita de televisão é ampliada principalmente pelo histórico de más gestões que grandes clubes brasileiros sofreram, causando uma maior dependência da mesma. A Globo considera o atual processo de profissionalização dos gestores de clubes brasileiros como um benefício para todos, pois o nível de negociação entre as partes eleva consideravelmente, e com isso pode-se chegar a melhores acordos para ambas as partes.

Quando o entrevistado foi questionado a respeito da influência que a Globo possa ter sobre os clubes do Brasil por ser detentora dos direitos de transmissão, ele afirma que não a considera influente, mas que está presente na cadeia, existindo um contrato a ser seguido e, por direito, a partir do momento que a Globo adquiri esses direitos, por contrato, ela define o horário de transmissão que seja interessante para ela, por exemplo. Esses horários possuem algumas restrições em função da grade de programação dos canais do grupo, mas ele também afirma que sempre existem conversas diárias com os clubes para que possam e se criar melhorias.

Um exemplo de mudança recente foi na alteração dos jogos de quarta-feira de noite, que antes eram às 22 horas, e passaram a iniciar às $21 \mathrm{~h} 45 \mathrm{~min}$, dessa forma, os jogos passaram a acabar mais cedo e a torcida conseguia utilizar o transporte publico a tempo. Outra alteração bem aceita foi a de colocar parte dos jogos do campeonato aos domingos de manha, que passaram a apresentar um publico melhor em função da grande aceitação por parte dos torcedores. Segundo a matéria publicada pela Folha de São Paulo, a média de público aumentou em 31\% para os jogos de domingo de manhã, (Folha.com.br, 2015).

No que diz respeito ao clube foco deste estudo, também foi abordado na entrevista a questão da Globo transmitir mais vezes em canal aberto os jogos do Flamengo que de seus rivais. O entrevistado afirma que os critérios de 
transmissão são feitos baseados no histórico que o grupo possui de audiência e, a partir do momento que os direitos são obtidos, a Globo tem liberdade de escolher o que será transmitido.

O Flamengo considera a Globo como o principal parceiro comercial do clube, não apenas representar a maior linha de receita, mas também por se tratar de um dos principais responsáveis pela construção do produto Futebol. São eles que utilizam esses direitos adquiridos para gerar um conteúdo que vai além de uma simples transmissão de jogo, a Globo é responsável por empacotar o produto para os torcedores assistirem, além de toda exposição que todos os seus canais de mídia geram para o Flamengo e seus patrocinadores. Se hoje o Flamengo tem a Globo como maior parceiro comercial, grande parte disso é por causa da torcida, a audiência que ela gera e o retorno que ela traz não só para o Flamengo mais também para a própria Globo.

\subsubsection{Stakeholder Torcida}

É consenso para os três entrevistados que a torcida do Flamengo é o maior patrimônio que o clube possui, trata-se do seu maior e principal ativo. Se o Flamengo possui a sua relevância no cenário do futebol, nível alto de arrecadação, e maior exposição por parte da mídia, o seu torcedor é o principal responsável. O representante do Flamengo afirma que é papel do clube criar e fornecer produtos para o torcedor, e que os mesmos atendam às suas demandas e necessidades, e com isso gere mais recursos para o clube. Esses recursos que serão usados para investir no departamento de futebol, para que o Flamengo obtenha mais títulos, mais ídolos, e fidelize cada vez mais o seu torcedor. Trata-se de um ciclo que o clube faz o máximo para que seja virtuoso, portanto, quanto mais o torcedor consumir, mais o Flamengo será capaz de entregar um produto melhor a ele.

Quando se analisa a torcida do Flamengo não se pode negar a disparidade de tamanho com relação à maioria de seus rivais. São mais de 32 milhões de torcedores de clube, sendo apenas o Corinthians, com cerca de 27 milhões, o mais próximo dele. Os outros times considerados de "massa" como o Vasco, São Paulo e Atlético Mineiro, por exemplo, são abaixo de 15 milhões de torcedores, (Globoesporte.com, 2014).

Uma pesquisa recentemente feita pelo Globo Esporte com parceria do Facebook em 2015 ilustra bem esse aspecto de disparidade. Na figura a seguir 
encontra-se um ranking de número de curtidas que a página oficial de cada time possui nos municípios do Brasil:

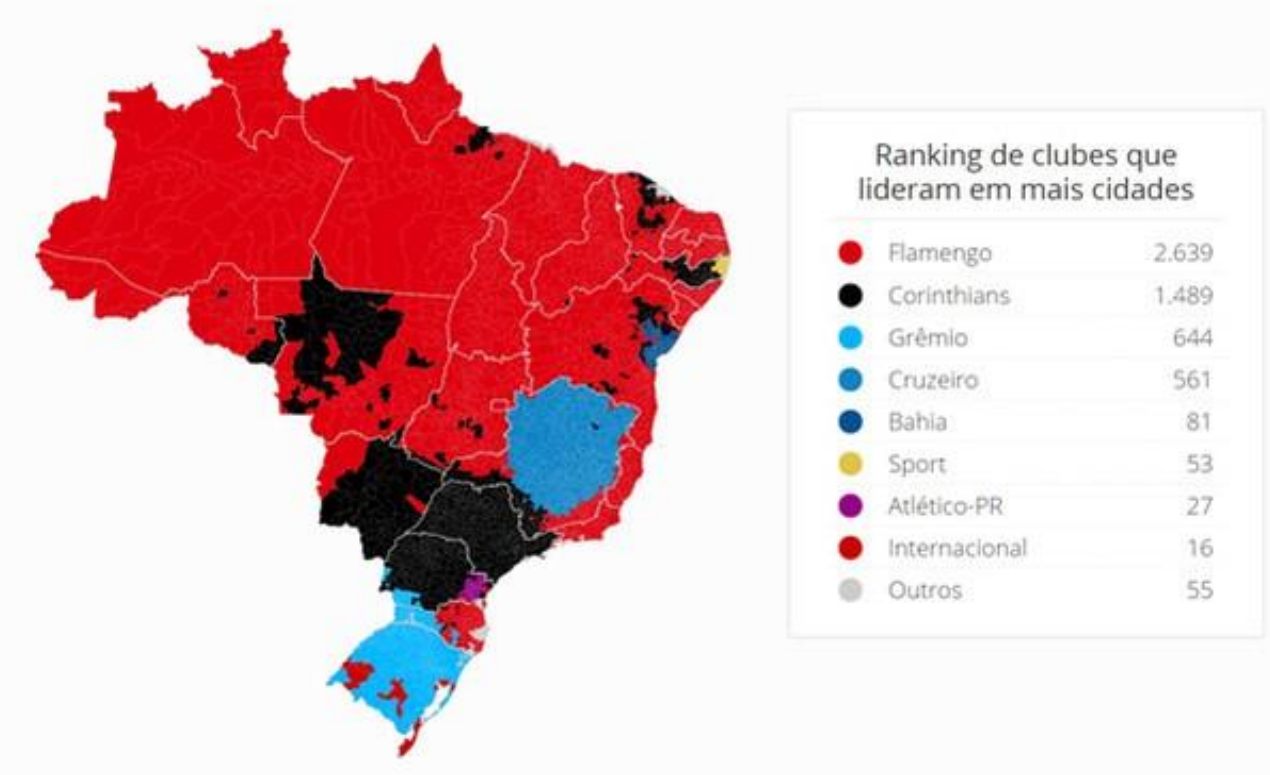

Figura 3 - Mapa de curtidas dos times no Brasil

(Fonte: Globoesporte.com, 2015)

Como se pode observar existe uma grande diferença de apelo de mídia que o Flamengo possui com relação aos demais. O que comprova a importância que o stakeholder torcida possui para o clube.

Questionado sobre a motivação que o torcedor do Flamengo tem para ir aos jogos do time, foi destacada a paixão como principal aspecto, contudo, atualmente são bem levados em consideração fatores como localização, horário da partida e, principalmente, o preço dos ingressos. No que diz respeito a precificação dos ingressos, em 2014 o Flamengo possuía o ticket médio mais caro do Brasil, o que causou na época diminuição de público nos jogos e, em função disso, resultados financeiros ruins (Globoesporte.com, 2014). Além disso, entrevistado também considera que existe pressão da torcida para que o clube precifique melhor os jogos, se tornando mais acessíveis, porém, a decisão final é do clube.

Sobre modelo atual de administração, regulação das dívidas, e de ser o clube brasileiro que melhor se destaca na parte de governança, segundo o entrevistado do Marketing do Flamengo, o representante da torcida considera o trabalho interno como bem executado. Segundo o funcionário do clube, o Flamengo diminuiu sua dívida pela metade praticamente, o que antes do 
Presidente Bandeira de Melo assumir era em torno de $R \$ 800$ milhões. Uma matéria publicada no site Globoesporte.com em março de 2016 comprova isso, onde aparece que o Flamengo terminou o ano de 2015 com um superávit de $R \$$ 130 milhões, e redução da dívida de $\mathrm{R} \$ 451$ Milhões, (Globoesporte.com, 2016). Contudo, para a maior parte da torcida, se os resultados em campo não correspondem, os aspectos positivos da gestão interna do Flamengo passam a ser muito pouco considerados. $O$ entrevistado reconhece que a torcida como um todo não enxerga os benefícios em longo prazo e exigem resultados imediatos.

No que diz respeito ao papel da torcida na contratação de atletas e treinadores, o entrevistado afirma que a torcida influencia e pressiona o clube nessa escolha, porém, não precisamente de um nome em si, mas sim de um profissional que seja acima da média no mercado, e que possa ser protagonista no time. Ele também cita o exemplo recente do jogador peruano Guerreiro, atleta do Flamengo desde o ano de 2015 (Espnuol.com, 2015). Além disso, quando o nome desejado é contratado, a torcida não se importa de se tratar de um jogador apalavrado ou com vínculo com outro time, pois, para ela, o principal é como o atleta poderá contribuir para o Flamengo independente dos preceitos éticos envolvidos na sua contratação.

Existe também outro lado, pois assim como a torcida pode ser capaz de ser decisiva para a contratação de um nome de peso, também pode contribuir para o afastamento de um profissional, seja ele jogador ou treinador. Um caso recente é do zagueiro Wallace, que bem próximo do início do campeonato Brasileiro de 2016 começar, pediu para ser afastado. Tratava-se do jogador mais cobrado e perseguido pela torcida do Flamengo e, neste caso específico, o jogador pediu para que fosse afastado, não foi uma atitude que se originou da direção do Flamengo, (Globoesporte.com, 2016).

Diferentemente do Flamengo, para o torcedor entrevistado existem stakeholders mais importantes que a Globo. Ele reconhece o protagonismo e a importância comercial que a Globo possui com o Flamengo e para o futebol brasileiro como um todo, mas considera a própria torcida, com destaque para os sócios com poder de voto e os conselheiros, que são torcedores que possuem mais poder sobre o clube, e também os patrocinadores que o time possui, como os stakeholders mais importantes. Mas ele considera que tanto o clube como os seus patrocinadores ainda pouco exploram o potencial de marca que o clube tem. E que se esse potencial fosse mais bem explorado o clube talvez estivesse numa situação melhor. 


\subsubsection{Processos decisórios do Flamengo}

Nos tópicos anteriores foram abordadas as relações existentes entre os stakoholders Globo e torcida com o Clube de Regatas Flamengo, já nessa etapa do estudo, encontram-se os processos de decisão que o clube executa ao ser influenciado pelos mesmos.

O Grupo Globo, como dito anteriormente, é considerado o principal parceiro comercial e, responsável pela maior linha de receita que o Flamengo recebe, através de contratos milionários de direitos de transmissão. Portanto, a Globo além de ter o controle de horários e que o time vai jogar, é influente ao ponto de fazer com que o Flamengo jogasse o Campeonato Carioca de 2016 com o time titular, sendo que a ideia anterior do clube era de priorizar a Primeira Liga e, segundo o representante do marketing do Flamengo, o Campeonato Estadual do Rio de Janeiro é deficitário para todos os clubes que participam, mas a Globo como detentora do direito enviou uma nota para o presidente do Flamengo pedindo que o clube revesse essa postura, (Esporteig.com, 2016).

$\mathrm{Na}$ entrevista com o membro do Grupo Globo, ele também afirma que existe a tentativa da Federação de futebol do estado do Rio de Janeiro, em parceria com a Globo, de se criar mudanças para que o Campeonato Carioca se torne um produto melhor e, não é à toa que nos últimos existiram mudanças no seu formato, (Globosporte.com, 2013). A ideia, segundo ele, sempre é de buscar um produto melhor e, por isso, no caso do Carioca de 2016 houve uma segunda fase de grupos, para que tivessem jogos considerados "clássicos" estaduais na maioria das rodadas. O Flamengo utilizou através do método racionalidade limitada, de se obter uma forte linha de receita com a Globo, para sanar suas dívidas, e se manter competitivo, porém, não considerou o lado da mesma como stakeholder envolvido. Como apresentado na teoria dos stakeholders, existe uma relação mutua entre as partes. Para a Globo não seria interessante o Flamengo abdicar do Campeonato Carioca para priorizar a primeira Liga e, se tratando do stakeholder que o clube considera principal parceiro comercial, o Flamengo acabou cedendo.

No que diz respeito à questão de adiantamentos de cotas de transmissão, o Flamengo atualmente, segundo o representante do clube, apresenta um modelo responsável de gestão, talvez um dos mais, se não o mais sensato do Brasil, mas afirma que a questão de cotas e como ela é gerenciada, é um assunto que corresponde ao departamento financeiro do clube, e não confirmou 
e nem negou a questão. Segundo uma matéria publicada pela ESPN em 2015, a própria Globo ofereceu um adiantamento de $\mathrm{R} \$ 20$ milhões aos clubes Campeonato Brasileiro da Seria A, para além de auxilia-los numa época de crise financeira, garantir a renovação de contrato de transmissão após 2018 (Espnuol.com.br, 2015). Não se sabe se o clube aceitou essa proposta e se a política de adiantamento de cotas é ainda presente.

Durante a entrevista com o representante do clube, alguns vieses de decisão se mostraram bem nítidos. Ao ser questionando a respeito dos principais stakeholders presentes no ambiente do Flamengo, ele afirma que o clube expõe sua marca e seus valores para não só os torcedores, mais também para quem não é, e afirma que a rejeição existente de outras torcidas é bem pequena. Contudo, segundo a pesquisa apresentada no mês de abril de 2016, o Flamengo é o segundo clube mais odiado por outros torcedores, perdendo apenas para o Corinthians, (Globoesporte.com, 2016). Trata-se de um viés de Evidencia Confirmadora, onde o entrevistado, através de fontes duvidosas, tenta passar a imagem para o entrevistador de que o Flamengo é um time apreciado por todos, não só pelo seu próprio torcedor. Outro viés desse aspecto é percebido quando o entrevistado afirma que o clube segue totalmente seu código de ética em todas as áreas, sendo que isso não acontece, como será abordado mais à frente, assim como outros vieses decisórios.

O Flamengo, assim como diversos clubes brasileiros, comumente troca de treinador (Esporteig.com, 2016), mas, dentre os clubes considerados grandes no cenário do futebol nacional, é o que mais trocou de técnico, sendo no total, nove profissionais distintos para o cargo desde 2012, (Foxsports.com.br, 2015). De acordo com o entrevistado do Flamengo, mesmo com os protestos da torcida, se trata de uma decisão única e exclusivamente feita pelo clube. Um caso emblemático foi o da demissão do Jaime de Almeida, que mesmo em 2013 sagrando-se campeão da Copa do Brasil e possuindo apoio da torcida, no início de 2014 a diretoria decidiu demiti-lo para contratar outro profissional (Espnuol.com.br, 2014), sendo que o sucessor Ney Franco, permaneceu poucos meses no cargo (Globoesporte.com, 2014). Embora os gestores do clube nesse aspecto se demonstrarem imparciais no que diz respeito aos protestos da torcida, diferentemente do que o representante da torcida abordou anteriormente, os mesmos apresentam métodos não apenas intuitivos na hora de decidir contratar um técnico, mas também vieses de compreensão tardia. $O$ que quer dizer que parecem agir mais de acordo com a emoção ao invés de considerar métodos mais racionais na hora de escolher um profissional que 
consiga apresentar um trabalho continuo, além disso, mesmo o clube trocando de treinador e os resultados não aparecendo, eles aparentam-se continuar com essa cultura de demissão, e aprendem pouco com os erros cometidos nesses aspectos.

O entrevistado ao abordar o planejamento do Flamengo, explica que ele é feito ano a ano, e que dificilmente um clube acerta em todas as decisões, sempre existem correções de rotas. Podem acontecer novas necessidades de contratação de atletas, seja por lesão ou por transferência. Talvez até ocorra de o elenco que se mostrava ideal, não apresentar resultados esperados, e com isso ocasionem mudanças. O próprio representante do clube considera um processo de tentativa e erro, o que demonstra um perfil voltado para realização, ou seja, são metas que precisam ser alcançadas, e caso não aconteçam, são necessárias mudanças, as falhas são pouco aceitas.

O entrevistado do clube quando questionado a respeito dos critérios de decisão para se contratar um atleta, ele afirma que se trata de uma decisão tomada através de critérios técnicos e esportivos, que se mostram baseados em critérios racionais de decisão. Nesse caso, o departamento de futebol identifica a necessidade do elenco, procuram alternativas no mercado, as avaliam e, por fim, se escolhe o profissional desejado. Nesse tipo de decisão, o departamento de futebol possui o maior peso, contudo, o entrevistado reconhece que a torcida também possui importância na escolha, até porque o jogador contratado precisa ser identificado e ser capaz de gerar retorno comercial para o clube. Conforme dito anteriormente, o representante da torcida afirma que existe influência da torcida quando ela pressiona o clube para que contrate um jogador mais qualificado, mas o clube afirma que os principais critérios são os técnicos e esportivos, baseados nas decisões do departamento de futebol.

Ainda sobre contratações, o próprio exemplo que o representante da torcida citou do atleta Guerreiro como um nome de peso que a mesma pedia na época e, que até o momento não rendeu o que foi esperado, atualmente possui futuro incerto no clube (Globoesporte.com, 2016). O Flamengo aparentemente se mostrou coerente sobre seu aspecto racional de decisão quando decidiu contrata-lo, por se tratar de um nome de peso que estava disponível no mercado, de ter sido destaque nas equipes que passou, e seria utilizado para fins comerciais para alavancar o projeto de sócio torcedor do clube (Globoesporte.com, 2015), utilizando a seguinte menção: "Guerreiro vem ai. É hora de você vir também". (Flamengo.com.br, 2015). Embora parecesse a melhor decisão a ser tomada, aconteceu que o próprio Presidente do clube, na 
época da contratação, afirmar se tratar de um jogador com histórico de muitos gols e que repetiria o mesmo sucesso no Flamengo, sendo que, segundo uma matéria publicada no Globo Esporte no ano de 2015, o jogador sempre apresentou médias baixas de gols nas outras equipes que atuou o que põe em dúvida a qualidade de tomada de decisão do Flamengo quando contratou o atleta. Neste caso foi percebido forte viés de excesso de confiança por parte do clube, de que o atleta renderia aquilo que eles imaginavam, e também o de ancoragem, pois o Flamengo demonstrou acreditar num profissional que já não estava rendendo tão bem no clube anterior, o Corinthians, mas que se havia se destacado em jogos decisivos no passado.

Um outro caso recente e emblemático de contratação envolveu o jogador Willian Arão. No caso em questão, o atleta ainda vinculado ao Botafogo, estava com o seu contrato próximo do término, e o mesmo ativou uma cláusula que permitia que o contrato se renovasse, contudo, o Flamengo entrou na disputa pelo atleta sem o consentimento do clube rival, que tinha interessa em manter o atleta. No desfecho, atleta acabou sendo contratado pelo Flamengo, e o Presidente do Botafogo criticou a postura do rival como sendo antiética, podendo prejudicar relações futuras entre os clubes, (globoesporte.com, 2015).

No que diz respeito à ética na contratação de atletas, o entrevistado afirmou ser uma questão a ser abordada apenas com o departamento de futebol do clube, mas que o clube possui um código de ética e o mesmo é seguido por todas as áreas. Contudo há uma incoerência por parte do entrevistado com relação às ações do clube, pois nesse caso, o clube estudado foi contra os preceitos presentes no seu próprio código de ética, onde o mesmo diz ser contra ao exercer influência sobre os outros, para que uma decisão a ser tomada para benefício próprio, (Código de ética do Flamengo, 2016, p.4). Nesse caso, a Instituição demonstrou-se antiética com o Botafogo por negociar e influenciar um atleta para que deixasse o clube e assina-se com o Flamengo, principalmente sem o consentimento do clube rival. O Flamengo utilizou-se do preceito de utilitarismo, pensando apenas no resultado da sua decisão e no benefício da maioria dos envolvidos, que no caso era contar com um atleta cobiçado no mercado, sendo dos três envolvidos, apenas um deles saiu-se prejudicado, que no caso foi o Botafogo.

A questão de preço dos ingressos, conforme visto anteriormente, vem sendo um fator de empecilho para que a torcida compareça em grande número nos jogos do time, segundo o representante de destaque da torcida. Contudo, de acordo com o atual membro do departamento de marketing, o Flamengo adota 
uma postura de decisão racional sobre esse aspecto. Segundo o mesmo, a influência do torcedor existe, mas não de forma direta, existem diversas variáveis que são levadas em consideração para se analisar a demanda que o jogo poça ter e, assim, estipular o valor do ingresso. Pode-se citar como exemplo, se o jogo é estreia de algum jogador e a fase que o time se encontra, mas, caso ocorra uma precificação errada, pode ocasionar uma renda abaixo do esperado para o clube. Ele explica, que caso o clube encareça demais os ingressos, acaba afastando a compra por parte da torcida, mas se diminui muito num caso de jogo de alta demanda, uma grande parte desses ingressos acabam nas mãos de cambistas. Ele reafirma a postura adotada de precificação do clube novamente utilizando o viés de evidencia confirmadora, ao afirmar que o mais importante para o torcedor é a saúde financeira Flamengo.

Por fim, outro ponto relevante no estudo é a influência que o stakeholder torcida, considerado pelo clube com o principal, possa ter nas decisões do clube no afastamento de atletas. Segundo o entrevistado, isso não acontece, apesar de reconhecer a existência de protestos por parte da torcida, isso não pesa na decisão do clube, contudo, conforme citado anteriormente pelo torcedor representante, essa influência existe, independente de se tratar de jogador ou de técnico. Isso ocorreu recentemente, quando vários jogadores foram afastados pela diretoria por aparecerem diversas vezes em festas e comemorações extracampo com o time do Flamengo vivenciando um mau momento no campeonato. Sendo que a maior parte desses atletas já possuíam relações ruins com a torcida, não só pelo desempenho abaixo da média em campo, mas por protagonizarem momentos, como o citado anteriormente, nas redes sociais. Houve até casos de depredação dos muros da sede do clube em protesto a esses profissionais (Globoesporte.com, 2015). Nesse aspecto, a decisão do Flamengo se mostrou racionalmente limitada no sentido de se mostrar de acordo com a torcida em não concordar com as práticas dos atletas, ou seja, a decisão se mostrou baseada nos protestos recentes e, não apenas pelos problemas internos dos jogadores. Embora os dois lados tenham sido levados em consideração, com mais peso o da torcida, os atletas foram reintegrados pouco tempo depois desse afastamento. Apesar punição ter sido divulgada por tempo indeterminado, os profissionais eram considerados peças importantes no elenco, o que impossibilitou que a mesma se mantivesse, (Odia.ig.com, 2015). A decisão se mostrou inconsistente, tanto por não se mostrar severa com os infratores e condizente com os valores do clube, quanto de acordo com os desejos da torcida, já que o tempo da punição e afastamento foi curto. 


\section{Conclusões e recomendações para novos estudos}

\subsection{Conclusões do estudo}

Este estudo teve como intuito abordar os processos de decisão organizacionais que são executados por um clube de futebol ao sofrer influência por parte de seus stakeholders.

Foi abordado primeiramente a contextualização do futebol e seus stakeholders como um todo, para que posteriormente o estudo apresentasse teorias que fundamentassem os conceitos a serem aplicados nos resultados da pesquisa.

$\mathrm{Na}$ etapa teórica o estudo apresentou, inicialmente, a teoria dos stakeholders, para melhor contextualização do seu papel num ambiente organizacional, possibilitando o melhor entendimento do seu papel no ambiente dos clubes de futebol. Já na segunda parte, foi apresentada de forma mais profunda os processos de decisão em uma organização, os seus níveis, as características dos seus atores, e os preceitos éticos envolvidos.

Para atingir os objetivos desse estudo, o autor utilizou-se de métodos de pesquisa exploratórios para a obtenção de dados tanto secundários quanto por meio de entrevistas pessoais. As fontes entrevistadas nesse estudo foram obtidas por critérios de acessibilidade por parte do pesquisador, uma vez que alguns potenciais entrevistados acabaram não tendo seu contato obtido. No tratamento de dados foram utilizados métodos qualitativos de análise, evitando todo o tipo de impureza nas amostras que pudessem prejudicar os resultados do estudo.

Os resultados foram apresentados através da aplicação das teorias previamente fundamentadas com os dados obtidos na etapa de pesquisa. Dessa forma, foi possível a identificação de diversos processos de tomada de decisão presentes no clube foco do estudo, o Flamengo, ao sofrer influência de dois fundamentais stakeholders, a torcida e o Grupo Globo.

Foi percebido o tamanho da importância que esses dois stakeholders possuem para o clube, uma vez que diversas tomadas de decisão giram em torno das relações existentes entre todas essas partes. A torcida foi apontada 
como o principal stakeholder dentre todos, já a Globo, o principal parceiro comercial do Flamengo. Ambos se mostram, primeiramente, imprescindíveis para a economia do clube, sendo a Globo responsável pela maior linha de receita que o Flamengo obtém atualmente e, a torcida que além de consumir todos os produtos vinculados ao clube, é responsável por toda a visibilidade de mídia que ele possui.

Os resultados também apontam que a Globo é o stakeholder influente no que se diz respeito às tomadas de decisão do Flamengo sobre as competições que o time joga e o uso da receita das cotas de transmissão que o clube adquiriu, além de toda a questão de horários que o grupo de mídia estipula para o clube jogar. Já a relação com o torcedor é diferente, pois estão presentes não apenas pela paixão de torcer e através do consumo da marca, mas também na influência de diversas decisões internas do clube.

O Flamengo apesar de se mostrar racional tanto no que diz respeito à contratação de atletas como na questão de precificação dos ingressos, reconhece o papel do torcedor nessas decisões. Para o torcedor entrevistado, o peso da torcida na contratação de um atleta existe e é fundamental, e no que diz respeito aos preços dos ingressos, o clube efetivamente acaba afastando os seus torcedores dos jogos devido à alta precificação.

Já no caso de afastamento de atletas, o estudo mostrou que a torcida pode ser um fator decisivo. Ela também parece não se importar tanto com os métodos utilizados pelo clube na obtenção de profissionais e, nem com a melhoria financeira do clube nos últimos anos. A torcida, como um todo, é aparentemente mais focada no resultado do time em curto prazo. Pode se dizer que para a torcida em geral, a qualidade da gestão é medida em função do numero de vitórias e títulos obtidos pelo time em campo.

O Flamengo apesar de aparentar um perfil de tomada de decisão voltado para realização, através de seus métodos de planejamento e gestão, comete diversas decisões racionalmente duvidosas e questionáveis não apenas em função de seus stakeholders abordados, mas também por meio de vieses e falhas decisórias. Todas essas decisões acabam influenciando não apenas o clube, mas todos os seus stakeholders envolvidos. 


\subsection{Recomendações para novos estudos}

Devido o estudo não abordar de forma profunda a gestão do clube, não se pode concluir que esses processos apresentados são os únicos existentes. Provavelmente existem muitos outros, mas conforme abordado anteriormente, 0 nível de acessibilidade do pesquisador foi limitado, impossibilitando a obtenção de maiores resultados sobre o clube.

Portanto, estudo tem um intuito de servir e base para novas pesquisas a respeito de tomada de decisão presente no clube, e que possam ser abordados novos ou mais stakeholders considerados importantes por parte do mesmo. Além disso, pode contribuir para novas pesquisas de tomada de decisão e influência dos stakeholders com outros clubes de futebol, não apenas no cenário nacional, como também times europeus de futebol.

O estudo de stakeholders é importante para entender de que forma a cadeia de cada clube é afetada por eles e, para os próprios clubes, pode ser de extrema valia entender como esses processos ocorrem, para assim conseguirem melhorar a qualidade de interação entre os numerosos agentes existentes no mercado.

O próprio estudo de tomada de decisão pode se tornar mais voltado para entidades de futebol, não só os clubes em si, mais todos os membros da cadeia, sejam eles, entidades esportivas, patrocinadores, atletas, arenas, etc. Existem ainda diversas possibilidades de estudo que podem enriquecer as ciências de administração e gestão do futebol. Esse estudo possui como base central fazer parte desse universo. 


\section{Referencias Bibliograficas}

Administradores.com 0 Modelo de Tomada de Decisão na área de Marketing. 26/09/2007. Disponível em:

http://www.administradores.com.br/artigos/marketing/o-modelo-comportamentalde-tomada-de-decisoes-na-area-de-marketing/14587/>.

Barry J. B. Princípios da Pesquisa de Marketing. 2. Ed. Learning, 2011.

Bazerman. M H., Moore. D. - Processo Decisório. 7. Ed Elsevier, 2009

Educação Uol. Biografias - Charles William Miller. Disponível

em:<http://educacao.uol.com.br/biografias/charles-william-miller.htm>.

Época. Quanto o Flamengo arrecadará com direitos de transmissão entre 2019 e 2024. 07/04/2016. Disponível em:

<http://epoca.globo.com/vida/esporte/noticia/2016/04/quanto-o-flamengoarrecadara-com-direitos-de-transmissao-entre-2019-e-2024.html>.

ESPN Uol. Flamengo anuncia Guerreiro por três anos; atacantes estreia depois da Copa América. 29/05/2015. Disponível em:

<http://espn.uol.com.br/noticia/513914_flamengo-anuncia-guerrero-por-tres-anosatacante-estreia-depois-da-copa-america>

ESPN Uol. Globo oferece a clubes adiantamento de $\mathbf{R} \mathbf{\$} \mathbf{2 0}$ milhões, sem juros e sem correção. 22/10/2015. Disponível em:

$<$ http://espn.uol.com.br/noticia/551902_globo-oferece-a-clubes-adiantamento-der-20-milhoes-sem-juros-e-correcao>.

ESPN UOL. Presidente do Flamengo sobre demissão do Jaime: "Hoje, faria diferente". 17/09/2014. Disponível em:

$<$ http://espn.uol.com.br/video/440615_presidente-do-flamengo-sobre-demissaode-jaime-hoje-faria-diferente $>$.

ESPN Uol. Procurada por clubes, Globo adota postura firme e nega antecipação de cotas de T.V. 29/09/2014. Disponível

em:<http://espn.uol.com.br/post/443555_procurada-por-clubes-globo-adotapostura-firme-e-nega-antecipacao-de-cotas-de-tv>.

ESPN Uol. Real Madrid Lidera lista de clubes mais ricos do mundo da revista Forbes. 06/05/2015. Disponível em:

http://espn.uol.com.br/noticia/507282_real-madrid-lidera-lista-de-clubes-maisricos-do-mundo-da-revista-forbes $>$.

Esporte IG. Flamengo cede á pressão da Globo e vai jogar Carioca com principais jogadores. 09/01/2016. Disponível em: 
<http://esporte.ig.com.br/futebol/2016-01-09/flamengo-cede-a-pressao-da-globoe-vai-jogar-carioca-com-principais-jogadores.html>.

Esporte IG. Troca de técnicos de time do Brasil supera a de europeus. Cariocas se destacam. 11/01/2016. Disponível em: <http://esporte.ig.com.br/futebol/2016-01-11/troca-de-tecnicos-de-times-dobrasil-supera-a-de-europeus-cariocas-se-destacam.html>

Esportes Terra. Corinthians é o Time $1^{\circ}$ fora da Europa entre os 20 mais ricos do Mundo. 2015. Disponível em:

$<$ http://esportes.terra.com.br/corinthians/corinthians-e-o-1-time-fora-da-europaentre-os-20-mais-ricos-domundo,eadf92dd6c91e310VgnVCM5000009ccceb0aRCRD.html>.

Esportes Terra. Torcida cobra Kayke na vaga de Guerreiro; "Cria” é melhor nos números. 29/09/2015. Disponível em:

$<$ http://esportes.terra.com.br/lance/torcida-cobra-kayke-na-vaga-de-guerrero-criae-melhor-nos-numeros, cae802b323ca6571656f1dac62a1a3093o9q3s88.html>.

Esportes Uol. Bom Senso se reúne com Globo, apresenta calendário e sai sem conclusões. 26/08/2014 Disponível

em:http://esporte.uol.com.br/futebol/ultimas-noticias/2014/08/26/bom-senso-fcse-reune-com-globo-apresenta-calendario-e-sai-sem-conclusoes.htm>.

Esporte Uol. Fla tem 8 jogadores em rota de colisão com torcida. Wallace lidera rejeição. 27/04/2016. Disponível em:

<http://esporte.uol.com.br/futebol/ultimas-noticias/2016/04/27/fla-tem-8-

jogadores-em-rota-de-colisao-com-torcida-wallace-lidera-rejeicao.htm>.

Estádio VIP. Maiores Patrocínios do Futebol Brasileiro. Disponível em: http://estadiovip.com.br/futebol/ranking/maiores-patrocinios-do-futebolbrasileiro/corinthians-caixa>.

Evan, W.M. , Freeman. R.E. - A Stakeholder Theory of the Modern Corporation: Kantian Capitalism, 1988.

Extra.Globo. Manchester United Lidera o Ranking dos maiores patrocínios do futebol mundial. 04/10/2014. Disponível em:<http://extra.globo.com/esporte/manchester-united-lidera-ranking-dosmaiores-patrocinios-do-futebol-mundial-14136781.html>.

Folha de São Paulo. Clubes chineses gastam mais e apostam em atletas no ápice. 17/01/2015. Disponível em:<http://www1.folha.uol.com.br/esporte/2015/01/1576443-clubes-chinesesgastam-mais-com-futebol-e-apostam-em-atletas-no-apice.shtml>.

Folha de São Paulo. Odiados por atletas, jogos às 11 horas têm público 31\% maior que a média. 14/09/2015. Disponível em: <http://www1.folha.uol.com.br/esporte/2015/09/1681277-odiados-por-atletasjogos-as-11-horas-tem-publico-31-maior-do-que-a-media.shtml>.

FoxSports. Treinadores do Flamengo da era Bandeira de Melo.

Disponível em: <http://www.foxsports.com.br/photos/11521/8-treinadores-do- 
flamengo-na-era-eduardo-bandeira> .

Freeman,R.E.- Strategic Management: A stakeholder approach. Boston: Pitman, 1984.

Futebol no Brasil. Origem do futebol no Brasil. Disponível em: <http://futebolno-brasil.info/origem-do-futebol-no-brasil.html>

Gil. A.C. Métodos e Técnicas de Pesquisa Social. 6. Ed. São Paulo: Atlas, 2008.

Globo Esporte. Caso Arão: Vasco ajuda, Botafogo usa Leandro Amaral e vê prazo de 60 dias. 19/02/2016. Disponível em:

<http://globoesporte.globo.com/futebol/noticia/2016/02/caso-arao-vasco-ajudabotafogo-usa-leandro-amaral-e-ve-prazo-de-60-dias.html>.

Globo Esporte. Centroavante ou $2^{\circ}$ atacante? Carreira prova que Guerreiro não é homem-gol. 04/11/2015. Disponível em:

<http://globoesporte.globo.com/futebol/times/flamengo/noticia/2015/11/centroava nte-ou-2-atacante-carreira-prova-que-guerrero-nao-e-homem-gol.html >.

Globo Esporte. Com ingresso mais caro, caem público e lucro do Flamengo no Maracanã. 16/09/2014. Disponível em:

<http://globoesporte.globo.com/blogs/especial-blog/dinheiro-em-jogo/post/comingresso-mais-caro-caem-publico-e-lucro-do-flamengo-no-maracana.html>.

Globo Esporte. Em arbitral, clubes aprovam mudança no formato do Carioca em 2014. 07/10/2013. Disponível em:

<http://globoesporte.globo.com/rj/futebol/campeonatocarioca/noticia/2013/10/em-arbitral-clubes-aprovam-mudanca-no-formato-docarioca-em-2014.html>.

Globo Esporte. Evolução das receitas dos direitos de transmissão e como ela é composta no Flamengo. 07/05/2015. Disponível em:

$<$ http://globoesporte.globo.com/blogs/especial-blog/olhar-cronico-

esportivo/post/evolucao-das-receitas-dos-direitos-de-transmissao.html>.

Globo Esporte. Espanhol é eleito o melhor campeonato do Mundo.

20/01/2015. Disponível em: < http://globoesporte.globo.com/futebol/futebolinternacional/noticia/2015/01/espanhol-e-eleito-melhor-campeonato-do-mundobrasileirao-fica-em-sexto.html>.

Globo Esporte. FIFA Proíbe investidores no futebol. 26/09/2014. Disponível em: <http://globoesporte.globo.com/blogs/especial-blog/bastidores-fc/post/fifaproibe-investidores-no-futebol.html>.

Globo Esporte. Flamengo anuncia a contratação do centroavante Guerreiro. 29/05/2015. Disponível em:

$<$ http://globoesporte.globo.com/futebol/times/flamengo/noticia/2015/05/flamengo -anuncia-contratacao-de-guerrero.html >

Globo Esporte. Flamengo confirma saídas de Jayme de Almeida e Paulo Pelaipe. 12/05/2014. Disponível em: 
<http://globoesporte.globo.com/futebol/times/flamengo/noticia/2014/05/flamengoconfirma-saidas-de-jayme-de-almeida-e-paulo-pelaipe.html>.

Globo Esporte. Incomodado, Guerreiro murcha no Flamengo e tem futuro indefinido. 23/05/2016. Disponível em:

$<$ http://globoesporte.globo.com/futebol/times/flamengo/noticia/2016/05/incomoda do-guerrero-murcha-no-flamengo-e-tem-futuro-indefinido.html $>$.

Globo Esporte. Investimento em Ascenção: o boom do futebol nos Estados Unidos. 22/04/2014. Disponível em:<http://globoesporte.globo.com/futebol/copado-mundo/noticia/2014/04/investimento-e-ascensao-o-boom-do-futebol-nosestados-unidos.html>.

Globo Esporte. Mapa revela times mais curtidos em cada uma das $\mathbf{5 . 5 7 0}$ cidades do Brasil. 25/09/2015. Disponível em:

<http://globoesporte.globo.com/futebol/noticia/2015/09/mapa-revela-times-maiscurtidos-do-brasil.html>.

Globo Esporte. O Bonde da stella e suas festas: do destaque ao descredito no Flamengo. 29/10/2015. Disponível em:

<http://globoesporte.globo.com/futebol/times/flamengo/noticia/2015/10/bonde-dastella-e-suas-festas-do-destaque-ao-descredito-no-flamengo.html>.

Globo Esporte. Pelo menos $80 \%$ dos jogadores brasileiros estão fatiados entre clubes e investidores.28/08/2014. Disponível em: <

http://globoesporte.globo.com/blogs/especial-blog/bastidores-fc/post/pelo-menos$80 \% 20$-dos-jogadores-brasileiros-estao-fatiados-entre-clubes-einvestidores.html>.

Globo Esporte. Ranking das torcidas: Fla se mantém no topo, e Corinthinas segue na cola. 27/08/2014. Disponível em:

<http://globoesporte.globo.com/futebol/noticia/2014/08/pesquisa-fla-tem-maiortorcida-mas-corinthians-encurta-distancia.html>.

Globo Esporte: Tudo sobre as audiências no Brasileirão 24/09/2013.

Disponível em: <http://globoesporte.globo.com/platb/teoria-dosjogos/2013/09/24/tudo-sobre-as-audiencias-do-brasileirao/>.

Globo Esporte. Willian Arão fecha com o Flamengo, e Muricy elogia:

"Volante Moderno". 14/12/2015. Disponível em:

<http://globoesporte.globo.com/futebol/times/flamengo/noticia/2015/12/oficial-

willian-aarao-e-anunciado-como-novo-reforco-do-flamengo.html>.

Globo Esporte. Zagueiro Wallace pede para sair do Fla, e Grêmio deve ser o destino . 13/05/2016. Disponível em:

<http://globoesporte.globo.com/futebol/times/flamengo/noticia/2016/05/zagueirowallace-comunica-saida-e-esta-fora-do-flamengo.html>.

Goldshimidt. A, Rocha. T. - Gestão dos Stakeholders . Ed. Saraiva. 2011

Judge. T.A. , Robbins. S.P. Sobral. S. - Comportamento Organizacional:

teoria e prática no contexto brasileiro. 14 Ed. São Paulo. 2011 
Mattar. M.F. - Na Trave - O que falta para o futebol Brasileiro ter uma gestão profissional. 1. Ed. Rio de Janeiro: Elsevier, 2014.

Moritz. G.O, Pereira. M.F. , Préve. A.D. - Organização e Processos e Tomada de Decisão. UFSC Universidade de Santa Catarina, 2010.

Noticias Uol. Clubes Brasileiros são sugados pelas federações de futebol19/04/2015.Disponível em:http://noticias.uol.com.br/opiniao/coluna/2015/04/19/clubes-brasileiros-saosugados-pelas-federacoes-de-futebol.htm>.

$\mathrm{O}$ dia IG. Flamengo reintegra os cinco jogadores afastados por festa realizada no Recreio. 04/11/2015. Disponível em:

<http://odia.ig.com.br/esporte/flamengo/2015-11-04/flamengo-reintegra-os-cincojogadores-afastados-por-festa-realizada-no-recreio.html>.

O Globo. O Grupo Globo é o $17^{\circ}$ maior conglomerado de mídia do mundo. 14/06/2016. Disponível em: <http://oglobo.globo.com/economia/grupo-globo-o17-maior-conglomerado-de-midia-do-mundo-16159426>.

Organizadas do Brasil. Torcidas Organizadas do Rio de Janeiro.

Disponível em:< http://www.organizadasbrasil.com/torcidas-organizadas-rio-dejaneiros.

Rede Globo. A Globo no Brasil. Disponível em:

$<$ http://redeglobo.globo.com/Portal/institucional/foldereletronico/g_globo_brasil.ht $\mathrm{ml}>$.

Sarmento. C. E. A Regra do Jogo - Uma história institucional da CBF.

CPDOC FGV. O 14/06/2016. CPDOC FGV, 2006

Página oficial do Flamengo. Código de Ética do Flamengo 2016.

Disponível em:<http://www.flamengo.com.br/site/download/baixar/157>

Steingraber. R. , Fernandez. R.G - A racionalidade limitada de Herbert Simon na Microeconomia, REVISTA Soc. Bras. Economia Política, São Paulo, 2013 Terceiro Tempo. "Espanholização" nas cotas de T.V assusta o futebol brasileiro. 24/04/2014. Disponível em:

<http://terceirotempo.bol.uol.com.br/noticias/reportagem-espanholizacao-na-tvassusta-futebol-brasileiro>.

Top 10 Mais. Os 10 Esportes mais populares do Mundo.16/09/2014.

Disponível em: http://top10mais.org/top-10-esportes-mais populares-mundo/. 


\section{Anexos}

\subsection{Roteiro de Entrevista - Clube de Regatas Flamengo}

$>$ Nome:

$>$ Organização:

$>$ Cargo:

> Breve resumo da função que ocupa e áreas de atuação:

> Quais os principais stakeholders do Flamengo ?

> Em linhas gerais, qual a importância da Globo para o Flamengo, como é essa relação?

> De que forma os horários das partidas, até o próprio calendário do futebol brasileiro, afeta o clube

> Você considera que o modelo de calendário e horários adequados?

> Ainda é presente no Flamengo a questão de adiantamento do cotas de transmissão ou houve alguma mudança em relação a gestão anterior, antes do presidente atual assumir?

> Entrando na questão das federações, em linhas gerais, qual o papel delas, tanto a FFERJ como a CBF em relação ao Flamengo?

> A FFERJ interfere de alguma forma na decisão do clube?

> No que diz respeito á estrutura do campeonato carioca, você a considera satisfatória?

$>$ Como o torcedor influencia o Flamengo?

$>$ Pode-se dizer então que o torcedor seja o Stakeholder que mais influencie as ações do clube?

> Qual o Peso, se é que ele existe, da torcida na contratação de um atleta?

> A Fase que o clube se encontra numa competição, pode ser um fator decisivo na contratação de um jogador?

> Quando a torcida protesta, seja com um técnico, ou com um jogador, acaba sendo levado em consideração pelo clube na hora se se tomar alguma decisão?

> Existe alguma influência da torcida na questão de precificação de ingressos? 
$>$ Existe algum preceito ético no que diz respeito na contratação de uma atleta?

Desses três stakeholders abordados, qual você considera como o mais importante? 


\subsection{Roteiro de entrevista - Grupo Globo}

$>$ Nome:

> Organização:

$>$ Cargo:

> Breve resumo da função que ocupa e áreas de atuação:

$>$ Quais são os principais Stakeholders do futebol brasileiro?

> Você considera Grupo Globo como o mais importante Stakeholder externo no Futebol Brasileiro? Por quê?

> Qual papel da Rede Globo como detentora dos direitos de transmissão?

$>$ Como são estipulados esses valores, e critérios utilizados? (audiência, tamanho de torcida, etc).

$>$ Por que existem times que ganham valores mais altos de direitos de transmissão?

$>$ Como são estipulados os horários de transmissão dos jogos?

> Até que ponto a rede Globo influencia na formulação de calendários e competições? Existe com clubes e federações?

$>$ Existe algum tipo de parceria entre a Globo como detentora dos direitos e as federações? Explique.

$>$ Se houvesse uma mudança no calendário, com menos jogos e horários, favorecendo mais aos clubes, será o futebol brasileiro se tornaria um produto melhor e de mais audiência?

$>$ A Rede Globo aderiria algum tipo de mudança? Por quê?

$>\mathrm{O}$ que a Globo sugere de mudanças para o Futebol Brasileiro e para os Clubes? 


\subsection{Roteiro de Entrevista - Representante da torcida}

$>$ Nome

$>$ Torcida:

$>$ Cargo na organizada:

$>$ Como a torcida foi criada?

$>$ Em linhas gerais, qual a importância da torcida do Flamengo para o clube?

$>$ O que motiva o torcedor para ir aos jogos do time?

$>$ Você acha que a torcida influencia o clube na precificação do ingresso?

$>$ Qual a opinião da torcida do flamengo sobre ele ser o um dos clubes que melhor se destaca no controle e regulação de seu orçamento e da sua dívida?

> Você acredita numa evolução do calendário do futebol? Qual seriam as vantagens para a torcida?

$>$ Qual a opinião da torcida do Flamengo jogar constantemente fora do Rio de Janeiro?

> Você acha que a torcida tem influência na contratação de um atleta ou de um técnico? Como?

> A torcida considera que os preceitos éticos devem ser preponderantes nas decisões de um clube? Por exemplo, na contratação de um atleta que se encontra empregado em outro clube.

> Quando a torcida faz algum tipo de protesto, você acha que pesa nas decisões do clube de alguma forma?

$>$ Quais são os maiores stakeholders no ambiente do Flamengo?

$>$ Como você vê a relação da Globo com o Flamengo?

$>$ Você considera a Globo um parceiro do Flamengo? 